\title{
Zeaxanthinibacter enoshimensis gen. nov., sp. nov., a novel zeaxanthin-producing marine bacterium of the family Flavobacteriaceae, isolated from seawater off Enoshima Island, Japan
}

\author{
Dalal Asker, Teruhiko Beppu and Kenji Ueda \\ Life Science Research Center, College of Bioresource Sciences, Nihon University, \\ 1866 Kameino, Fujisawa 252-8510, Japan
}

Correspondence

Kenji Ueda

ueda@brs.nihon-u.ac.jp

\begin{abstract}
A novel marine, Gram-negative, yellow-pigmented, rod-shaped, strictly aerobic, gliding and oxidase- and catalase-positive bacterium (strain TD-ZE3 ${ }^{\top}$ ) was isolated from a seawater sample collected off the Pacific coastline of Japan near Enoshima Island (Fujisawa, Kanagawa). Phylogenetic analysis based on $16 \mathrm{~S}$ rRNA gene sequences revealed that strain TD-ZE3 ${ }^{\top}$ belonged to a distinct lineage in the family Flavobacteriaceae, with $90.5 \%$ sequence similarity with the nearest species Robiginitalea biformata. Strain TD-ZE3 ${ }^{\top}$ could be distinguished from other members of the family Flavobacteriaceae by a number of chemotaxonomic and phenotypic characteristics. The DNA G $+\mathrm{C}$ content was $46.5 \mathrm{~mol} \%$. The major fatty acids were iso- $\mathrm{C}_{15: 0 \text {, }}$ iso- $\mathrm{C}_{17: 0} 3-\mathrm{OH}$ and iso- $\mathrm{C}_{17: 1} \omega 9 \mathrm{c}$ and menaquinone- 6 was the only respiratory quinone. Zeaxanthin was the major carotenoid pigment produced; flexirubin-type pigments were not produced. Strain TD-ZE3 ${ }^{\top}$ degraded gelatin, starch and Tween 80. Based on its unique phenotypic, genotypic and phylogenetic features, strain TD-ZE3 ${ }^{\top}$ represents a novel taxon, for which the name Zeaxanthinibacter enoshimensis gen. nov., sp. nov. is proposed. The type strain is TD-ZE3 ${ }^{\top}$ $\left(=\right.$ NBRC $101990^{\top}=$ CCUG $\left.53613^{\top}\right)$.
\end{abstract}

At the time of writing, the family Flavobacteriaceae (Bernardet et al., 2002; Reichenbach, 1989) in the phylum Bacteroidetes comprises 44 genera. Many members of this family were isolated from various marine and/or Antarctic habitats (Bowman et al., 1997, 1998; Bowman, 2000; Bowman \& Nichols, 2002, 2005; Cho \& Giovannoni, 2004; Nedashkovskaya et al., 2004d; Nichols et al., 2005; Pinhassi et al., 2006; Suzuki et al., 2001). These bacteria are known to be proficient in degrading various biopolymers such as cellulose, chitin and pectin (Kirchman, 2002); hence, they are considered to be important members of the bacterial community involved in metabolic activities in aquatic environments.

In order to study the industrial application of microbial carotenoid production, we screened bacterial strains that produce useful carotenoids, including zeaxanthin. Zeaxanthin $\left(3,3^{\prime}\right.$-dihydroxy- $\beta$-carotene $)$ is an oxygenated, yellow carotenoid that is found naturally in corn, alfalfa and marigolds (Nelis \& De Leenheer, 1989). This pigment is currently used as an ingredient in feed for fish and poultry,

The GenBank/EMBL/DDBJ accession number for the 16S rRNA gene sequence of strain TD-ZE3 ${ }^{\top}$ is AB264057.

Scanning electron micrographs of cells of strain TD-ZE3 ${ }^{\top}$ are available as supplementary material in IJSEM Online. to enhance the pigmentation of animal flesh and egg yolk. In addition, zeaxanthin has a remarkable potential for use in pharmaceuticals as it prevents age-related macular degeneration. Micro-organisms that produce zeaxanthin belong to various taxa; they include Synechocystis sp. PCC 6803 (Lagarde et al., 2000), Erwinia herbicola (Hundle et al., 1993), Paracoccus zeaxanthinifaciens (Berry et al., 2003; McDermott et al., 1973) and Sphingobacterium multivorum (Alcantara \& Sanchez, 1999; Rosa-Putra et al., 2001). Here, we report the isolation and characterization of a novel zeaxanthin-producing marine bacterium that belongs to the family Flavobacteriaceae.

We isolated a new strain, designated TD-ZE3 ${ }^{\mathrm{T}}$, by plating a seawater sample collected off the Pacific coastline of Japan near Enoshima Island (Fujisawa, Kanagawa; $35.3^{\circ} \mathrm{N}$ $139.5^{\circ} \mathrm{E}$ ) on 10 April 2005 onto marine agar 2216 (MA; Difco) and incubating at $30^{\circ} \mathrm{C}$ for $48 \mathrm{~h}$. Unless otherwise specified, all characteristics described hereafter are those of cells of strain TD-ZE3 $3^{\mathrm{T}}$ grown on MA for $48 \mathrm{~h}$ at $30^{\circ} \mathrm{C}$.

The genomic DNA of strain TD-ZE3 ${ }^{\mathrm{T}}$ was extracted using a bacterial genomic DNA purification kit (Edge BioSystems) and the nearly complete 16S rRNA gene sequence (1431 bp) was amplified using the bacterial universal primers $\mathrm{B} 8 \mathrm{~F}$ (5'-AGAGTTTGATCCTGGCTCAG-3'; nt 8-27 based on 
Escherichia coli numbering) and B1492R (5'-GGTTACCTTGTTACGACTT-3'; nt 1508-1484 based on Escherichia coli numbering). The $16 \mathrm{~S}$ rRNA gene fragment was sequenced directly using a BigDye Terminator v3.1 Cycle sequencing kit and an ABI 3100 automated DNA sequencer (Applied Biosystems).

A sequence similarity search in the GenBank/EMBL/ DDBJ nucleotide sequence databases performed using the program BLASTN (http://www.ncbi.nlm.nih.gov/blast/) revealed that strain $\mathrm{TD}-\mathrm{ZE} 3^{\mathrm{T}}$ belonged to the family Flavobacteriaceae. A neighbour-joining phylogenetic tree was constructed using the programs CLUSTAL W (Thompson et al., 1994) and NJ plot (Perriere \& Gouy, 1996). The tree topology was estimated by using a bootstrap analysis (Felsenstein, 1993) with 1000 resamplings of the dataset. Strain $\mathrm{TD}_{\mathrm{ZEE}}{ }^{\mathrm{T}}$ formed a clade together with several uncharacterized bacterial strains with sequence similarities of $95-98 \%$. This clade did not cluster robustly with any recognized species or genus. Strain TD-ZE3 ${ }^{\mathrm{T}}$ shared $90.5 \%$ $16 \mathrm{~S}$ rRNA gene sequence similarity with Robiginitalea biformata HTCC $2501^{\mathrm{T}}$ without significant bootstrap support (Fig. 1). Sequence similarities between strain TD$\mathrm{ZE}^{\mathrm{T}}$ and other relatives ranged from 89.2 to $91.3 \%$; they include Cellulophaga pacifica (91.3\%), Maribacter species (90.2-90.4\%), Zobellia species (89.2-89.8\%), Sediminicola luteus (89.8\%) and Arenibacter species (89.6-89.7\%). A tree based on the maximum-likelihood method showed essentially the same topology (data not shown). The results of the phylogenetic analysis suggest that strain $\mathrm{TD}-\mathrm{ZE} 3^{\mathrm{T}}$ represents a novel genus within the family Flavobacteriaceae.

Gram staining was performed according to the method described by Smibert \& Krieg (1994) and bacterial cells were

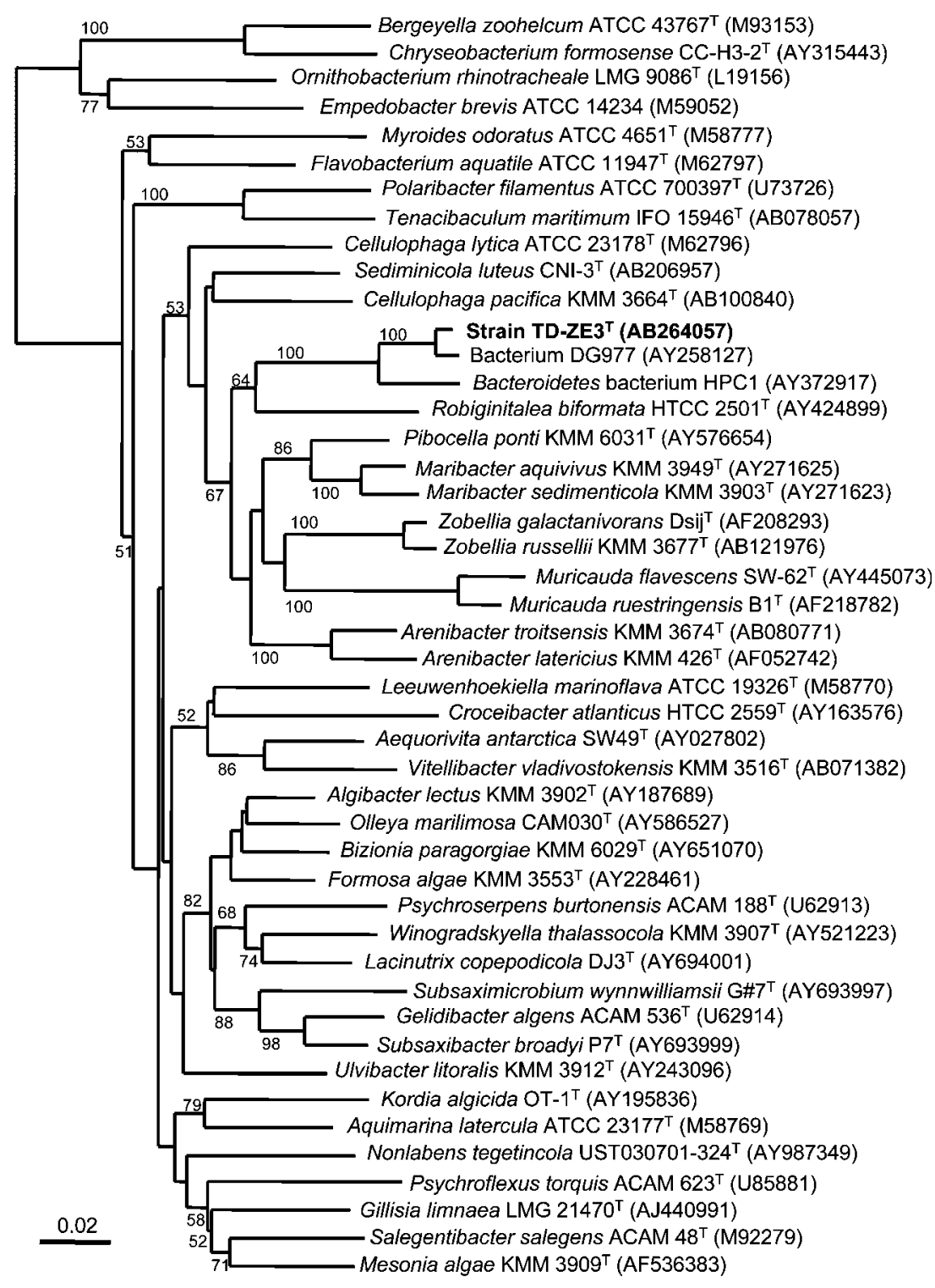

Fig. 1. Phylogenetic tree based on $16 \mathrm{~S}$ rRNA gene sequences of strain TD-ZE3 ${ }^{\top}$ and representative members of related genera in the family Flavobacteriaceae. The tree was constructed using the neighbourjoining method (Saitou \& Nei, 1987). GenBank accession numbers are shown in parentheses. Numbers at nodes indicate bootstrap values greater than $50 \%$. The 16S rRNA gene sequences of Flexibacter flexilis ATCC $23079^{\top}$ (GenBank accession no. M62794) and Chlorobium limicola UdG_6037 (AJ299414) were used as outgroups (not shown). Bar, 0.02 substitutions per nucleotide position. 
observed under a Zeiss Axioskop 2 microscope (Carl Zeiss Microimaging). Scanning electron microscopy was performed according to the method described by Bruns et al. (2001), using a model VE-8800 (Keyence). Flagellar and gliding motilities were determined using the hanging drop method and gliding motility was examined further using phase-contrast microscopy of growth margins of strain TD$\mathrm{ZE} 3^{\mathrm{T}}$ grown for $1-2$ days at $30^{\circ} \mathrm{C}$ on $0.1 \times \mathrm{MA}$ [containing $0.1 \%$ marine broth (MB; Difco) and $1 \%$ agar] (Bowman, 2000). Anaerobic growth was assessed on MA incubated in a GasPak anaerobic system (BBL). The following tests were performed as described in each reference cited: casein hydrolysis (Norris et al., 1985), Tween 80 hydrolysis (Baumann \& Baumann, 1988), catalase activity, spore formation and hydrolysis of DNA and starch (Smibert \& Krieg, 1994), and hydrolysis of chitin, carboxymethylcellulose (high viscosity; Sigma) and agar (Cowan \& Steel, 1993). Oxidase activity was studied by spreading the bacterial cells on a cytochrome oxidase strip (BioChemika) to observe a colour change. Other enzyme activities, growth on carbohydrates, acid production from carbohydrates, nitrate reduction and the production of $\mathrm{H}_{2} \mathrm{~S}$, indole and acetoin were examined using the commercial systems API 20E, API $20 \mathrm{NE}$ and API $50 \mathrm{CH}$ (bioMérieux) according to the manufacturer's instructions and as described by Nichols et al. (2005). These systems were inoculated with bacterial suspensions in media containing $32 \mathrm{~g}$ synthetic sea salts $\mathrm{l}^{-1}$ (Sigma). To determine the optimal growth temperature, strain TD-ZE3 ${ }^{\mathrm{T}}$ was cultivated on MA at $4,10,20,30,37,40$ and $45^{\circ} \mathrm{C}$. The requirement for $\mathrm{NaCl}$ was studied using a medium containing the following $\left(\mathrm{l}^{-1}\right): 5 \mathrm{~g} \mathrm{MgCl}_{2}, 2 \mathrm{~g}$ $\mathrm{MgSO}_{4}, 0.5 \mathrm{~g} \mathrm{CaCl}_{2}, 1 \mathrm{~g} \mathrm{KCl}, 5 \mathrm{~g}$ Bacto peptone (Difco), $1 \mathrm{~g}$ Bacto yeast extract (Difco) and varying amounts of $\mathrm{NaCl}(1$, $1.5,3,5,7,10$ or $12 \%$ ) ( $\mathrm{pH}$ adjusted to 7.5 using $\mathrm{KOH}$ ). Growth at various $\mathrm{pH}$ values $(\mathrm{pH} 3.0-10.0)$ was evaluated in $\mathrm{MB}$ adjusted with $\mathrm{HCl}$ or $\mathrm{NaOH}$. Phenotypic properties of strain $\mathrm{TD}-\mathrm{ZE} 3^{\mathrm{T}}$ are given in the species description and those characteristics that differentiate strain TD-ZE $3^{\mathrm{T}}$ from related members of the family Flavobacteriaceae are listed in Table 1.

Cells of strain $\mathrm{TD}-\mathrm{ZE} 3^{\mathrm{T}}$ were Gram-negative rods of $0.2-0.4 \mu \mathrm{m}$ in width and $1.2-3.9 \mu \mathrm{m}$ in length, motile by gliding and occasionally formed vesicle-like microstructures

Table 1. Characteristics that differentiate Zeaxanthinibacter enoshimensis gen. nov., sp. nov. TD-ZE ${ }^{\top}$ from related genera of the family Flavobacteriaceae

Taxa: 1, strain TD-ZE3 ${ }^{\mathrm{T}}$; 2, R. biformata HTCC $2501^{\mathrm{T}}$ (data from Cho \& Giovannoni, 2004); 3, Maribacter (5 species) (Nedashkovskaya et al., 2004d; Yoon et al., 2005b); 4, Pibocella ponti KMM 6031 ${ }^{\mathrm{T}}$ (Nedashkovskaya et al., 2005); 5, Zobellia (5 species) (Barbeyron et al., 2001; Nedashkovskaya et al., 2004b); 6, Muricauda (3 species) (Bruns et al., 2001; Yoon et al., 2005a); 7, Arenibacter (4 species) (Ivanova et al., 2001; Nedashkovskaya et al., 2003, 2004a, 2006); 8, Cellulophaga (4 species) (Bowman, 2000; Johansen et al., 1999; Nedashkovskaya et al., 2004c). +, Positive; -, negative; ND, not determined; v, variable.

\begin{tabular}{|c|c|c|c|c|c|c|c|c|}
\hline Characteristic & 1 & 2 & 3 & 4 & 5 & 6 & 7 & 8 \\
\hline Oxidase/catalase & $+1+$ & $+/+$ & $+/+$ & $+1+$ & $+/+$ & $+/ \mathrm{V}$ & $+1+$ & $+1+$ \\
\hline Gliding motility & + & - & + & + & + & $\mathrm{V}$ & $\mathrm{V}$ & + \\
\hline Flexirubin pigments & - & - & - & - & + & - & - & - \\
\hline Requirement of $\mathrm{Na}^{+}$ & + & + & + & + & + & + & $\mathrm{V}$ & + \\
\hline \multicolumn{9}{|l|}{ Growth at/in: } \\
\hline $7 \% \mathrm{NaCl}$ & + & + & $\mathrm{V}$ & + & $\mathrm{v}$ & + & $\mathrm{v}$ & $\mathrm{V}$ \\
\hline $4^{\circ} \mathrm{C}$ & - & - & + & + & $\mathrm{v}$ & - & $\mathrm{v}$ & + \\
\hline $40^{\circ} \mathrm{C}$ & + & + & - & - & $\mathrm{V}$ & + & $\mathrm{V}$ & $\mathrm{V}$ \\
\hline $42^{\circ} \mathrm{C}$ & - & + & - & - & $\mathrm{V}$ & $\mathrm{V}$ & $\mathrm{v}$ & - \\
\hline Gelatin & + & - & $\mathrm{V}$ & + & + & - & $\mathrm{V}$ & + \\
\hline Starch & + & + & $\mathrm{V}$ & + & $\mathrm{V}$ & - & - & + \\
\hline DNA & - & - & $\mathrm{V}$ & - & $\mathrm{V}$ & $-/ \mathrm{ND}$ & $\mathrm{V}$ & $\mathrm{V}$ \\
\hline Urea & - & - & - & - & - & $-/ \mathrm{ND}$ & $\mathrm{v}$ & $\mathrm{ND}$ \\
\hline Nitrate reduction & - & - & $\mathrm{V}$ & - & + & $\mathrm{V}$ & $\mathrm{V}$ & $\mathrm{V}$ \\
\hline DNA G $+\mathrm{C}$ content $(\mathrm{mol} \%)$ & 46.5 & $55-56$ & $35-39$ & 35.5 & $36-43$ & $41-45$ & $37-40$ & $32-34$ \\
\hline
\end{tabular}

${ }^{*}$ Abbreviations: DO, deep orange; O, orange; Y, yellow. 
Table 2. Whole-cell fatty acid profiles of Zeaxanthinibacter enoshimensis gen. nov., sp. nov. TD-ZE3 ${ }^{\top}$ and related genera in the family Flavobacteriaceae

Taxa: 1, strain TD-ZE3 ${ }^{\mathrm{T}}$; 2, R. biformata HTCC $2501^{\mathrm{T}}$ (data from Cho \& Giovannoni, 2004); 3, Maribacter (5 species) (Nedashkovskaya et al., 2004d; Yoon et al., 2005b); 4, Pibocella ponti KMM 6031 ${ }^{\mathrm{T}}$ (Nedashkovskaya et al., 2005); 5, Zobellia (5 species) (Barbeyron et al., 2001; Nedashkovskaya et al., 2004b); 6, Muricauda (3 species) (Bruns et al., 2001; Yoon et al., 2005a); 7, Arenibacter (4 species) (Ivanova et al., 2001; Nedashkovskaya et al., 2003, 2004a, 2006); 8, Cellulophaga (4 species) (Bowman, 2000; Johansen et al., 1999; Nedashkovskaya et al., 2004c). Data are reported as percentages of the total fatty acids. For genera that comprise several species, data are reported as a range of percentages of total fatty acids. tr, Trace amount $(<1 \%)$; , not detected. Fatty acids amounting to less than $1 \%$ in all taxa studied are not listed.

\begin{tabular}{|c|c|c|c|c|c|c|c|c|}
\hline Fatty acid & 1 & 2 & 3 & 4 & 5 & 6 & 7 & 8 \\
\hline \multicolumn{9}{|l|}{ Saturated acids: } \\
\hline $\mathrm{C}_{14: 0}$ & - & - & - & - & $\operatorname{tr}-1.0$ & - & - & - \\
\hline $\mathrm{C}_{15: 0}$ & 7.7 & 5.5 & $3.5-14.5$ & 4.2 & $7.5-14.4$ & $5.1-13.2$ & $4.2-16.0$ & $9.3-14.3$ \\
\hline $\mathrm{C}_{16: 0}$ & $\operatorname{tr}$ & 1.3 & $\operatorname{tr}-1.4$ & 1.0 & $\operatorname{tr}-2.6$ & $\operatorname{tr}$ & $\operatorname{tr}-2.7$ & $1.2-3.4$ \\
\hline \multicolumn{9}{|c|}{ Branched saturated acids: } \\
\hline iso- $\mathrm{C}_{14: 0}$ & - & - & - & 1.0 & - & $\operatorname{tr}$ & - & - \\
\hline iso- $\mathrm{C}_{15: 0}$ & 18.9 & 26.0 & $10.6-20.5$ & 8.7 & $16.8-22.5$ & $14.7-23.8$ & $6.8-15.8$ & $6.1-21.4$ \\
\hline anteiso- $\mathrm{C}_{15: 0}$ & 2.3 & 3.7 & $\operatorname{tr}-2.3$ & 5.4 & $1.0-1.8$ & $1.1-2.5$ & $3.2-13.5$ & $1.0-2.6$ \\
\hline iso- $\mathrm{C}_{16: 0}$ & 1.1 & - & $\operatorname{tr}-1.1$ & 12.1 & - & $\operatorname{tr}$ & - & $\operatorname{tr}-2.7$ \\
\hline \multicolumn{9}{|l|}{ Monounsaturated acids: } \\
\hline $\mathrm{C}_{14: 1} \omega 5 c$ & - & - & - & $\operatorname{tr}-1.0$ & - & - & - & - \\
\hline $\mathrm{C}_{15: 1} \omega 6 c$ & $\operatorname{tr}$ & - & $\operatorname{tr}-4.8$ & 1.5 & $1.1-3.2$ & $\operatorname{tr}$ & $1.0-2.6$ & $1.4-2.6$ \\
\hline $\mathrm{C}_{16: 1} \omega 7 c$ & - & - & - & - & - & - & - & $9.0-19.2$ \\
\hline $\mathrm{C}_{17: 1} \omega 8 c$ & $\operatorname{tr}$ & - & - & - & - & $\operatorname{tr}$ & $\operatorname{tr}-2.4$ & - \\
\hline $\mathrm{C}_{17: 1} \omega 6 c$ & 1.0 & - & $\operatorname{tr}-1.7$ & 4.7 & $1.0-1.2$ & $\operatorname{tr}-1.0$ & $\operatorname{tr}-3.0$ & - \\
\hline $\mathrm{C}_{18: 1} \omega 6 c$ & - & - & - & - & $\operatorname{tr}-1.1$ & - & - & - \\
\hline \multicolumn{9}{|c|}{ Branched monounsaturated acids: } \\
\hline iso- $\mathrm{C}_{15: 1}$ & - & 17.2 & $10.1-18.9$ & 11.7 & $8.8-14.9$ & - & $4.9-14.0$ & $13.1-20.9$ \\
\hline anteiso- $\mathrm{C}_{15: 1}$ & - & - & - & 2.1 & $0.0-1.8$ & - & $\operatorname{tr}-2.9$ & - \\
\hline iso- $\mathrm{C}_{15: 1} \omega 10 c$ & - & - & - & - & - & - & - & $7.5-10.3$ \\
\hline iso- $\mathrm{C}_{15: 1} \mathrm{G}$ & 9.9 & - & - & - & - & $19.5-21.6$ & - & - \\
\hline iso- $\mathrm{C}_{16: 1}$ & - & - & - & 6.2 & - & $\operatorname{tr}$ & $\operatorname{tr}-1.7$ & - \\
\hline iso- $\mathrm{C}_{16: 1} \omega 6 c$ & - & - & - & - & - & - & - & $1.1-2.2$ \\
\hline iso- $\mathrm{C}_{17: 1} \omega 9 c$ & 13.3 & - & 2.3 & 5.2 & $2.4-5.1$ & $1.3-1.5$ & $2.2-5.3$ & - \\
\hline anteiso- $\mathrm{C}_{17: 1} \omega 9 c$ & - & - & - & 2.3 & - & - & - & - \\
\hline iso- $\mathrm{C}_{17: 1} \omega 7 c$ & - & - & - & - & - & - & - & $5.1-6.7$ \\
\hline anteiso- $\mathrm{C}_{17: 1} \omega 7 c$ & - & - & - & - & - & - & - & $\operatorname{tr}-1.5$ \\
\hline iso- $\mathrm{C}_{18: 1}$ & - & - & $0.0-2.4$ & - & - & - & - & - \\
\hline \multicolumn{9}{|l|}{ Hydroxy acids: } \\
\hline $\mathrm{C}_{15: 0} 2-\mathrm{OH}$ & - & - & - & 1.8 & - & $\operatorname{tr}$ & $\operatorname{tr}-1.0$ & - \\
\hline $\mathrm{C}_{15: 0} 3-\mathrm{OH}$ & - & 4.3 & $1.4-2.4$ & - & $\operatorname{tr}$ & $1.0-1.8$ & $\operatorname{tr}-2.2$ & $\operatorname{tr}$ \\
\hline $\mathrm{C}_{16: 0} 3-\mathrm{OH}$ & - & - & $2.2-5.5$ & 1.0 & $2.4-4.9$ & $\operatorname{tr}$ & $1.0-3.8$ & $\operatorname{tr}-1.9$ \\
\hline $\mathrm{C}_{17: 0} 2-\mathrm{OH}$ & $\operatorname{tr}$ & 1.2 & - & 2.8 & - & $\operatorname{tr}-1.4$ & $1.0-5.1$ & - \\
\hline $\mathrm{C}_{17: 0} 3-\mathrm{OH}$ & - & - & - & - & - & $\operatorname{tr}-1.3$ & - & - \\
\hline iso- $\mathrm{C}_{15: 0} 3-\mathrm{OH}$ & 2.7 & - & $2.9-5.4$ & $\operatorname{tr}$ & $4.6-8.3$ & $4.6-5.5$ & $3.5-5.7$ & $3.2-8.6$ \\
\hline anteiso- $\mathrm{C}_{15: 0} 3-\mathrm{OH}$ & - & - & - & - & - & - & - & $\operatorname{tr}-1.8$ \\
\hline iso- $\mathrm{C}_{16: 0} 3-\mathrm{OH}$ & 2.4 & - & $1.0-2.5$ & 5.9 & - & $1.7-4.6$ & $1.6-7.2$ & $5.0-7.3$ \\
\hline iso- $\mathrm{C}_{17: 0} 3-\mathrm{OH}$ & 16.5 & 25.8 & $11.6-29.2$ & 5.6 & $15.1-25.9$ & $17.3-20.9$ & $6.9-21.9$ & $2.8-20.8$ \\
\hline Summed feature $3^{*}$ & 5.8 & 3.5 & $5.8-12.9$ & 11.4 & $9.9-15.5$ & $2.3-4.2$ & $9.6-13.5$ & - \\
\hline ECL $13.56 \dagger$ & 11.0 & - & - & - & $1.4-2.4$ & $4.8-6.5$ & - & - \\
\hline Others & 2.1 & - & $2.7-10.3$ & 5.5 & - & $1.6-2.3$ & - & - \\
\hline
\end{tabular}

${ }^{\star}$ Summed feature 3 comprises iso- $\mathrm{C}_{15: 0} 2-\mathrm{OH}$ and/or $\mathrm{C}_{16: 1} \omega 7 c$.

$\dagger$ Unknown fatty acids designated by their equivalent chain-length (ECL). 
(see Supplementary Fig. S1 in IJSEM Online). After incubation at $30^{\circ} \mathrm{C}$ for $48 \mathrm{~h}$, colonies on MA were circular, 2-4 mm in diameter, yellow-pigmented, shiny and convex, with smooth surfaces and entire translucent margins.

As no flexirubin-type pigments were detected using the simple $\mathrm{KOH}$ test detailed in the minimal standards for describing new taxa of the family (Bernardet et al., 2002), the yellow pigments were extracted by agitating bacterial cells in methanol on a rotary shaker $(100$ r.p.m. $)$ at $50^{\circ} \mathrm{C}$ in the dark until the cells were bleached, followed by centrifugation at $5000 \mathrm{~g}$ for $5 \mathrm{~min}$. The absorbance of the resultant supernatant was determined between $\lambda=260$ and $700 \mathrm{~nm}$ at room temperature using a Hitachi U2000 spectrophotometer. Carotenoid composition was characterized by using HPLC-MS (LCMS-2010EV; Shimadzu) using a Shim-Pack FC-ODS $(150 \times 4.6 \mathrm{~mm}, 5 \mu \mathrm{m}$ particle size; column temperature $35^{\circ} \mathrm{C}$ ) and acetonitrile/methanol/tetrahydrofurane $(5.8: 3.5: 0.7$, by vol.) as a mobile phase at a flow rate of $0.8 \mathrm{ml} \mathrm{min}^{-1}$. Zeaxanthin was identified from its retention time, absorption spectrum and molecular mass. Commercial zeaxanthin (DHI; Water \& Environment) was used as a standard. The menaquinone content was determined by using an HPLC method (Collins, 1994) with an extract of cells of Cellulophaga lytica as a reference for menaquinone- 6 (MK-6; Johansen et al., 1999). The fatty acid methyl esters of strain TD-ZE $3^{\mathrm{T}}$ were extracted and analysed according to the standard protocol of the Sherlock Microbial Identification System (version 5.0; MIDI).

The yellow pigments of strain TD-ZE3 ${ }^{\mathrm{T}}$ were identified as carotenoids, among which zeaxanthin was predominant [UV-Vis $\lambda_{\max }$ of 451 and $476 \mathrm{~nm}$ and molecular mass $\left.(M+\mathrm{H})^{+}, 569\right]$. MK-6 was found to be the only respiratory quinone. The predominant cellular fatty acids were iso$\mathrm{C}_{15: 0}$, iso- $\mathrm{C}_{17: 0} 3-\mathrm{OH}$, iso- $\mathrm{C}_{17: 1} \omega 9 c$, iso- $\mathrm{C}_{15: 1} \mathrm{G}, \mathrm{C}_{15: 0}$ and an unknown fatty acid with an equivalent chain-length (ECL) of 13.56 . These fatty acids represented $77.3 \%$ of the total fatty acids of strain TD-ZE3 ${ }^{\mathrm{T}}$. The detailed fatty acid composition of strain TD-ZE3 ${ }^{\mathrm{T}}$ is shown in Table 2. It differed from those reported for R. biformata HTCC $2501^{\mathrm{T}}$ by the absence of iso- $\mathrm{C}_{15: 1}$ and the presence of iso- $\mathrm{C}_{15: 1} \mathrm{G}$, iso- $\mathrm{C}_{17: 1} \omega 9 c$ and ECL 13.56 (Table 2). Strain TD-ZE3 ${ }^{\mathrm{T}}$ differed from members of all related genera except Muricauda species by the absence of iso- $\mathrm{C}_{15: 1}$.

The DNA G $+\mathrm{C}$ content of strain $\mathrm{TD}-\mathrm{ZE}^{\mathrm{T}}{ }^{\mathrm{T}}$, determined using HPLC (Mesbah \& Whitman, 1989), was $46.5 \pm$ $0.3 \mathrm{~mol} \%$ (mean $\pm \mathrm{SD}$, three replicates). This value was $10 \mathrm{~mol} \%$ lower than that of R. biformata HTCC $2501^{\mathrm{T}}$ and higher than those of related members of the genera Maribacter, Pibocella and Cellulophaga (Table 1).

Based on the results of the 16S rRNA gene-based phylogenetic analysis and on the above-mentioned phenotypic features, we conclude that strain TD-ZE3 ${ }^{\mathrm{T}}$ represents a novel genus within the family Flavobacteriaceae, for which we propose the name Zeaxanthinibacter enoshimensis gen. nov., sp. nov.

\section{Description of Zeaxanthinibacter gen. nov.}

Zeaxanthinibacter (Ze.a.xan'thi.ni.bac'ter. N.L. neut. n. zeaxanthinum zeaxanthin; N.L. masc. n. bacter from Gr. n. bakterion rod; N.L. masc. n. Zeaxanthinibacter zeaxanthinproducing rod-like bacterium).

Gram-negative, non-spore-forming rods and motile by gliding. Strictly aerobic. Catalase- and oxidase-positive. MK-6 is the only respiratory quinone. Carotenoid pigments are produced, but not flexirubin-type pigments. The $\mathrm{G}+\mathrm{C}$ content of the type strain of the type species is $46.5 \mathrm{~mol} \%$. The type species is Zeaxanthinibacter enoshimensis.

\section{Description of Zeaxanthinibacter enoshimensis sp. nov.}

Zeaxanthinibacter enoshimensis (en.o.shi.men'sis. N.L. masc. adj. enoshimensis pertaining to Enoshima Island in Japan, where the type strain was isolated).

Displays the following characteristics in addition to those given in the genus description. Cells are $0.2-0.4 \mu \mathrm{m}$ in width and 1.2-3.9 $\mu \mathrm{m}$ in length; some cells show the presence of vesicle-like microstructures. On MA, colonies $(2.0-4.0 \mathrm{~mm}$ in diameter) are convex, translucent, shiny and smooth and contain non-diffusible yellow carotenoid pigments with zeaxanthin as the major component. Growth occurs at $16.0-40.0^{\circ} \mathrm{C}$ (optimum, $28.0-30.0^{\circ} \mathrm{C}$ ) and at $\mathrm{pH} 5.5-11.0$ (optimum, 7.0-8.0). Optimal growth occurs in the presence of $4 \%(\mathrm{w} / \mathrm{v}) \mathrm{NaCl}$; growth is inhibited in the absence of $\mathrm{NaCl}$ and in the presence of $>8 \%(\mathrm{w} / \mathrm{v}) \mathrm{NaCl}$. Aesculin, Tween 80 , gelatin and starch are hydrolysed, but agar, DNA, casein, cellulose, chitin and urea are not. Indole and $\mathrm{H}_{2} \mathrm{~S}$ are not produced. Nitrate is not reduced. $\beta$-Galactosidase activity is positive. Tryptophan deaminase, lysine decarboxylase, ornithine decarboxylase, tryptophan deaminase and urease activities are negative. Acid is produced from glucose, mannose, methyl $\alpha$-D-mannoside, methyl $\alpha$-D-glucoside, aesculin, cellobiose, maltose, lactose, melibiose, sucrose, trehalose, melezitose, raffinose, arabinose and D-turanose. Glucose, maltose, mannose, mannitol, $N$-acetylglucosamine and gluconate are assimilated, but arabinose, capric acid, adipic acid, malate, trisodium citrate and phenylacetic acid are not. Predominant cellular fatty acids (representing $77.3 \%$ of the total fatty acids) are iso- $\mathrm{C}_{15: 0}$, iso- $\mathrm{C}_{17: 0} 3-\mathrm{OH}$, iso- $\mathrm{C}_{17: 1} \omega 9 c$, iso- $\mathrm{C}_{15: 1} \mathrm{G}, \mathrm{C}_{15: 0}$ and an unknown fatty acid with an ECL of 13.56. The DNA G $+\mathrm{C}$ content of the type strain is $46.5 \mathrm{~mol} \%$.

The type strain, TD-ZE3 ${ }^{\mathrm{T}}\left(=\mathrm{NBRC} 101990^{\mathrm{T}}=\mathrm{CCUG}\right.$ $\left.53613^{\mathrm{T}}\right)$, was isolated from a shallow seawater sample collected off the Pacific coastline of Japan near Enoshima Island.

\section{Acknowledgements}

We would like to thank the two anonymous referees and the editor whose insightful suggestions significantly improved the paper. We thank Shoichi Amano for his assistance with the electron microscopy 
observations. This research was supported by the 21st century COE program of the Ministry of Education, Culture, Sports, Science and Technology, Japan. D. A. was supported by a fellowship from the Japan Society for the Promotion of Science.

\section{References}

Alcantara, S. \& Sanchez, S. (1999). Influence of carbon and nitrogen sources on Flavobacterium growth and zeaxanthin biosynthesis. J Ind Microbiol Biotechnol 23, 697-700.

Barbeyron, T., L'Haridon, S., Corre, E., Kloareg, B. \& Potin, P. (2001). Zobellia galactanovorans gen. nov., sp. nov., a marine species of Flavobacteriaceae isolated from a red alga, and classification of [Cytophaga] uliginosa (ZoBell and Upham 1944) Reichenbach 1989 as Zobellia uliginosa gen. nov., comb. nov. Int J Syst Evol Microbiol 51, 985-997.

Baumann, P. \& Baumann, L. (1988). The marine gram-negative eubacteria: genera Photobacterium, Beneckea, Alteromonas, Pseudomonas and Alcaligenes. In The Prokaryotes, pp. 1302-1331. Edited by M. P. Starr, H. Stolp, H. G. Trüper, A. Balows \& H. G. Schlegel. Berlin: Springer.

Bernardet, J.-F., Nakagawa, Y. \& Holmes, B. (2002). Proposed minimal standards for describing new taxa of the family Flavobacteriaceae and emended description of the family. Int J Syst Evol Microbiol 52, 1049-1070.

Berry, A., Janssens, D., Hümbelin, M., Jore, J. P. M., Hoste, B., Cleenwerck, I., Vancanneyt, M., Bretzel, W., Mayer, A. F. \& other authors (2003). Paracoccus zeaxanthinifaciens sp. nov., a zeaxanthinproducing bacterium. Int J Syst Evol Microbiol 53, 231-238.

Bowman, J. P. (2000). Description of Cellulophaga algicola sp. nov., isolated from the surfaces of Antarctic algae, and reclassification of Cytophaga uliginosa (ZoBell and Upham 1944) Reichenbach 1989 as Cellulophaga uliginosa comb. nov. Int J Syst Evol Microbiol 50, 1861-1868.

Bowman, J. P. \& Nichols, D. S. (2002). Aequorivita gen. nov., a member of the family Flavobacteriaceae isolated from terrestrial and marine Antarctic habitats. Int J Syst Evol Microbiol 52, 1533-1541.

Bowman, J. P. \& Nichols, D. S. (2005). Novel members of the family Flavobacteriaceae from Antarctic maritime habitats including Subsaximicrobium wynnwilliamsii gen. nov., sp. nov., Subsaximicrobium saxinquilinus sp. nov., Subsaxibacter broadyi gen. nov., sp. nov., Lacinutrix copepodicola gen. nov., sp. nov., and novel species of the genera Bizionia, Gelidibacter and Gillisia. Int J Syst Evol Microbiol 55, 1471-1486.

Bowman, J. P., McCammon, S. A., Brown, J. L., Nichols, P. D. \& McMeekin, T. A. (1997). Psychroserpens burtonensis gen. nov., sp. nov., and Gelidibacter algens gen. nov., sp. nov., psychrophilic bacteria isolated from Antarctic lacustrine and sea ice habitats. Int J Syst Bacteriol 47, 670-677.

Bowman, J. P., McCammon, S. A., Lewis, T., Skerratt, J. H., Brown, J. L., Nichols, D. S. \& McMeekin, T. A. (1998). Psychroflexus torquis gen. nov., sp. nov., a psychrophilic species from Antarctic sea ice, and reclassification of Flavobacterium gondwanense (Dobson et al. 1993) as Psychroflexus gondwanense gen. nov., comb. nov. Microbiology 144, 1601-1609.

Bruns, A., Rohde, M. \& Berthe-Corti, L. (2001). Muricauda ruestringensis gen. nov., sp. nov., a facultatively anaerobic, appendaged bacterium from German North Sea intertidal sediment. Int J Syst Evol Microbiol 51, 1997-2006.

Cho, J.-C. \& Giovannoni, S. J. (2004). Robiginitalea biformata gen. nov., sp. nov., a novel marine bacterium in the family Flavobacteriaceae with a higher $\mathrm{G}+\mathrm{C}$ content. Int J Syst Evol Microbiol 54, 1101-1106.
Collins, M. D. (1994). Isoprenoid quinones. In Chemical Methods in Prokaryotic Systematics, pp. 265-310. Edited by M. Goodfellow \& A. G. O'Donnell. Chichester: Wiley.

Cowan, S. T. \& Steel, K. J. (1993). Manual for the Identification of Medical Bacteria, 3rd edn. Cambridge: Cambridge University Press.

Felsenstein, J. (1993). PHYLIP (phylogeny inference package), version 3.5. Distributed by the author. Department of Genome Sciences, University of Washington. Seattle, USA.

Hundle, B. S., O'Brien, D. A., Beyer, P., Kleinig, H. \& Hearst, J. E. (1993). In vitro expression and activity of lycopene cyclase and $\beta$-carotene hydroxylase from Erwinia herbicola. FEBS Lett 315, 329-334.

Ivanova, E. P., Nedashkovskaya, O. I., Chun, J., Lysenko, A. M., Frolova, G. M., Svetashev, V. I., Vysotskii, M. V., Mikhailov, V. V., Huq, A. \& Colwell, R. R. (2001). Arenibacter gen. nov., new genus of the family Flavobacteriaceae and description of a new species, Arenibacter latericius sp. nov. Int J Syst Evol Microbiol 51, 1987-1995.

Johansen, J. E., Nielsen, P. \& Sjøholm, C. (1999). Description of Cellulophaga baltica gen. nov., sp. nov. and Cellulophaga fucicola gen. nov., sp. nov. and reclassification of [Cytophaga] lytica to Cellulophaga lytica gen. nov., comb. nov. Int J Syst Bacteriol 49, 1231-1240.

Kirchman, D. L. (2002). The ecology of Cytophaga-Flavobacteria in aquatic environments. FEMS Microbiol Ecol 39, 91-100.

Lagarde, D., Beuf, L. \& Vermaas, W. (2000). Increased production of zeaxanthin and other pigments by application of genetic engineering techniques to Synechocystis sp. strain PCC 6803. Appl Environ Microbiol 66, 64-72.

McDermott, J. C., Britton, G. \& Goodwin, T. W. (1973). Carotenoid biosynthesis in a Flavobacterium sp.: stereochemistry of hydrogen elimination in the desaturation of phytoene to lycopene, rubixanthin and zeaxanthin. Biochem J 134, 1115-1117.

Mesbah, M. \& Whitman, W. B. (1989). Measurement of deoxyguanosine/thymidine ratios in complex mixtures by high-performance liquid chromatography for determination of the mole percentage guanine + cytosine of DNA. J Chromatogr 479, 297-306.

Nedashkovskaya, O. I., Suzuki, M., Vysotskii, M. V. \& Mikhailov, V. V. (2003). Arenibacter troitsensis sp. nov., isolated from marine bottom sediment. Int J Syst Evol Microbiol 53, 1287-1290.

Nedashkovskaya, O. I., Kim, S. B., Han, S. K., Lysenko, A. M., Mikhailov, V. V. \& Bae, K. S. (2004a). Arenibacter certesii sp. nov., a novel marine bacterium isolated from the green alga Ulva fenestrata. Int J Syst Evol Microbiol 54, 1173-1176.

Nedashkovskaya, O. I., Suzuki, M., Vancanneyt, M., Cleenwerck, I., Lysenko, A. M., Mikhailov, V. V. \& Swings, J. (2004b). Zobellia amurskyensis sp. nov., Zobellia laminariae sp. nov. and Zobellia russellii sp. nov., novel marine bacteria of the family Flavobacteriaceae. Int J Syst Evol Microbiol 54, 1643-1648.

Nedashkovskaya, O. I., Suzuki, M., Lysenko, A. M., Snauwaert, C., Vancanneyt, M., Swings, J., Vysotskii, M. V. \& Mikhailov, V. V. (2004c). Cellulophaga pacifica sp. nov. Int J Syst Evol Microbiol 54, 609-613.

Nedashkovskaya, O. I., Kim, S. B., Han, S. K., Lysenko, A. M., Rohde, M., Rhee, M.-S., Frolova, G. M., Falsen, E., Mikhailov, V. V. \& Bae, K. S. (2004d). Maribacter gen. nov., a new member of the family Flavobacteriaceae, isolated from marine habitats, containing the species Maribacter sedimenticola sp. nov., Maribacter aquivivus sp. nov., Maribacter orientalis sp. nov. and Maribacter ulvicola sp. nov. Int J Syst Evol Microbiol 54, 1017-1023.

Nedashkovskaya, O. I., Kim, S. B., Lee, K. H., Bae, K. S., Frolova, G. M., Mikhailov, V. V. \& Kim, I. S. (2005). Pibocella ponti gen. nov., sp. nov., a novel marine bacterium of the family Flavobacteriaceae 
isolated from the green alga Acrosiphonia sonderi. Int J Syst Evol Microbiol 55, 177-181.

Nedashkovskaya, O. I., Vancanneyt, M., Cleenwerck, I., Snauwaert, C., Kim, S. B., Lysenko, A. M., Shevchenko, L. S., Lee, K. H., Park, M. S. \& other authors (2006). Arenibacter palladensis sp. nov., a novel marine bacterium isolated from the green alga Ulva fenestrata, and emended description of the genus Arenibacter. Int J Syst Evol Microbiol 56, 155-160.

Nelis, H. J. \& De Leenheer, A. P. (1989). Profiling and quantitation of bacterial carotenoids by liquid chromatography and photodiode array detection. Appl Environ Microbiol 55, 3065-3071.

Nichols, C. M., Bowman, J. P. \& Guezennec, J. (2005). Olleya marilimosa gen. nov., sp. nov., an exopolysaccharide-producing marine bacterium from the family Flavobacteriaceae, isolated from the Southern Ocean. Int J Syst Evol Microbiol 55, 1557-1561.

Norris, J. R., Ribbons, D. W. \& Varma, A. K. (1985). Methods in Microbiology. London: Academic Press.

Perriere, G. \& Gouy, M. (1996). WWW-query: an on-line retrieval system for biological sequence banks. Biochimie 78, 364-369.

Pinhassi, J., Bowman, J. P., Nedashkovskaya, O. I., Lekunberri, I., Gomez-Consarnau, L. \& Pedrós-Alió, C. (2006). Leeuwenhoekiella blandensis sp. nov., a genome-sequenced marine member of the family Flavobacteriaceae. Int J Syst Evol Microbiol 56, 1489-1493.

Reichenbach, H. (1989). Order I. Cytophagales Leadbetter 1974, 99 ${ }^{\mathrm{AL}}$. In Bergey's Manual of Systematic Bacteriology, pp. 2011-2013. Edited by J. T. Staley, M. P. Bryant, N. Pfennig \& J. G. Holt. Baltimore: Williams \& Wilkins.

Rosa-Putra, S., Hemmerlin, A., Epperson, J., Bach, T. J., Guerra, L. H. \& Rohmer, M. (2001). Zeaxanthin and menaquinone-7 biosynthesis in Sphingobacterium multivorum via the methylerythritol phosphate pathway. FEMS Microbiol Lett 204, 347-353.

Saitou, N. \& Nei, M. (1987). The neighbor-joining method: a new method for reconstructing phylogenetic trees. Mol Biol Evol 4, 406-425.

Smibert, R. M. \& Krieg, N. R. (1994). Phenotypic characterization. In Methods for General and Molecular Bacteriology, pp. 607-654. Edited by P. Gerhardt, R. G. E. Murray, W. A. Wood \& N. R. Krieg. Washington, DC: American Society for Microbiology.

Suzuki, M., Nakagawa, Y., Harayama, S. \& Yamamoto, S. (2001). Phylogenetic analysis and taxonomic study of marine Cytophaga-like bacteria: proposal for Tenacibaculum gen. nov. with Tenacibaculum maritimum comb. nov. and Tenacibaculum ovolyticum comb. nov., and description of Tenacibaculum mesophilum sp. nov. and Tenacibaculum amylolyticum sp. nov. Int J Syst Evol Microbiol 51, 1639-1652.

Thompson, J. D., Higgins, D. G. \& Gibson, T. J. (1994). CLUSTAL W: improving the sensitivity of progressive multiple sequence alignment through sequence weighting, position-specific gap penalties and weight matrix choice. Nucleic Acids Res 22, 4673-4680.

Yoon, J.-H., Lee, M.-H., Oh, T.-K. \& Park, Y.-H. (2005a). Muricauda flavescens sp. nov. and Muricauda aquimarina sp. nov., isolated from a salt lake near Hwajinpo Beach of the East Sea in Korea, and emended description of the genus Muricauda. Int J Syst Evol Microbiol 55, 1015-1019.

Yoon, J.-H., Kang, S.-J., Lee, S.-Y., Lee, C.-H. \& Oh, T.-K. (2005b). Maribacter dokdonensis sp. nov., isolated from sea water off a Korean island, Dokdo. Int J Syst Evol Microbiol 55, 20512055. 